\title{
Active learning in online teaching in SMA Swakarya Binjai
}

\author{
E.D.Tarigan ${ }^{1 *}$, Ujian Sinulingga ${ }^{1}$, Sawaluddin ${ }^{1}$, Agus Salim Harahap ${ }^{1}$, Open Darnius ${ }^{1}$ \\ ${ }^{1}$ Departments of Mathematics, Faculty of Mathematics and Natural Science, Universitas \\ Sumatera Utara, Medan, Indonesia \\ *Email: enitadewi@usu.ac.id
}

\begin{abstract}
Nowadays, the education world in learning method is not only using a conventional method, which is basically, by an explanation from a teacher and merely from the learning books. But, with an effective and efficient learning method, so that the students are able to keep up and participate actively during the lesson, by taking an advantage of IT (Information Technology), especially for facing the changes in learning due to pandemic COVID-19. The contribution from people is one of the ways to carry out the socialisation of information technology. This community service, will be implemented in this research entitled "Active Learning in Online Teaching, in Swakarya Senior High School, Binjai", with an intention to assist teachers while in the process of learning, to be more interesting and enjoyable although it is done through a distance learning. The learning application will be given to all of the senior high school teachers, as is to prepare and use this learning application, in order to broaden the perception and to motivate the teachers, and eventually they will be able to motivate the students as well. Moreover, this will help to upgrade the quality of education.
\end{abstract}

Keyword: School, E-learning, Education, Technologi

\begin{abstract}
Abstrak
Dunia pendidikan pada saat ini dalam metode pembelajaran tidak hanya menggunakan metode konvensional yaitu dengan penjelasan dari guru saja atau hanya dari buku-buku pelajaran akan tetapi dengan metode pembelajaran efektif dan efesien agar peserta didik dapat mengikuti pelajaran dengan aktif yaitu memanfaatkan teknologi informasi khususnya dalam menghadapi perubahan pembelajaran akibat pandemic Covid-19. Pengabdian pada masyarakat merupakan salah satu cara yang dapat dimanfaatkan dalam melaksanakan pemasyarakatan teknologi informasi. Pengabdianmasyarakat ini akan dilaksanakan pada penelitian ini berjudul Pembelajaran Aktif Dalam Jaringan (Daring) Untuk Tingkat Sekolah Menengah Atas di SMA Swasta SWAKARYA Binjai dengan tujuan membantu guru-guru dalam proses pembelajaran yang lebih menarik dan menyenangkan walaupun dilakukan pembelajaran jarak jauh. Aplikasi pembelajaran akan diberikan pada guru-guru di Sekolah Menengah Atas (SMA) sebagaimana menyiapkan dan menggunakan aplikasi pembelajaran sehingga mampu menambah wawasan dan motivasi guru dan akhirnya dapat memotivasi siswa yang secara garis lurus akaan meningkatkan mutu pendidikan.
\end{abstract}

Kata Kunci: Sekolah, Pembelajaran Daring, Pendidikan, Tekhnologi

\section{PENDAHULUAN (INTRODUCTION)}

Pandemi Corona Virus Disease 2019 (Covid-19) memamksa dunia pendidikan untuk ikut menerapkan physical distancing (menjaga jarak fisik) dan Kemendikbud ( Kementrian Pendidikan dan Kebudayaan) merespon dengan kebijakan belajar dari rumah melalui pembelajaran daring. System pembelajaran daring (dalam jaringan) merupakan pembelajaran tanpa tatap muka secara langsung antara guru dan siswa tetapi dilakukan melalui online yang menggunakan jaringan internet. 
Guru dituntut dapat medesain media pembelajaran sebagai inovasi dengan memanfaatkan media daring (online). Pembelajaran daring menjadi masalah ketika guru belum mempunyai persiapan yang matang untuk proses pembelajaran yang lancar dan siswa dapat aktif mengikuti pelajaran walaupun dalam kondisi pandemic Covid-19.

Untuk Mencari solusi dalam hal mengatasi masalah tersebut sehingga guru dapat mendesain media pembelajaran yang inovasi dan dapat meningkatkan minat belajar siswa serta prestasi belajar siswa pada semua pelajaran. Dalam kegiatan belajar mengajar yang monoton dan hanya memberi tugas lewat whatsupp dapat di bantu dengan menggunakan aplikasi gratis di internet. Kerumitan bahan pelajaran dapat disederhanakan dan penyampain pelajaran dapat dibuat dengan menarik. Oleh karena itu dalam rangka membantu meningkatkan mutu pendidikan dan pengajaran maka perlu memanfaatkan perkembangan teknologi computer.

Dalam internet didapat aplikasi gratis yaitu google meet, google classroom, google formulir dan zoom. Pemanfaatan aplikasi tersebut akan memudahkan guru menyampaikan materi pembelajaran dan mengadakan ujian juga pemberian tugas walau penyampaian dengan jarak jauh. Dengan adanya aplikasi ini diharapkan dapat memudahkan dan menyenangkan dalam memahami dan mempelajari materi yang diberikan. Siswa juga dapat membuka aplikasi tersebut lewat handphone sehingga mudah bagi siswa untuk mengikuti pelajaran jarak jauh.

Penggantian sistem ini diharapkan dapat memberikan informasi yang akurat, menghemat biaya dan waktu, sehingga dalam proses belajar mengajar seluruh siswa dapat mengerti materi pelajaran tersebut. Kemajuan teknologi komputer dapat membantu seluruh aspek kehidupan manusia. Permasalahannya belum banyak sekolah yang mempunyai sarana dan prasaran untuk mendukung pembelajaran jarak jauh. Dan banyak siswa yang merasa jenuh dengan sistem pembelajaran yang monoton dengan hanya memberi tugas lewat whatsupp

\section{METODE PELAKSANAAN (METHODS)}

Pengabdian ini dilaksanakan pada kurun waktu 6 bulan yaitu Bulan Juni sampai Bulan November dengan memberikan pelatihan kepada guru-guru SMA SWASTA SWAKARYA Binjai dengan tujuan guru-guru dapat melaksanakan kegiatan belajar mengajar jarak jauh dengan menggunakan metode pembelajaran aktif dalam jaringan (daring) yang berbasis teknologi informasi. Dalam pelaksana pengabdian ini diberikan pelatihan tentang pembelajaran aktif jarak jauh menggunakan aplikasi yang gratis. Pelatihan pembuatan bahan ajar berbasis metode pembelajaran aktif dengan mengunakan Teknologi Informasi yaitu Google meet, Zoom maupun penyiapan bahan ajar dengan Google Classroom dan Google formulir. Untuk mendukung pelatihan yang di berikan maka mitra akan diberikan perangkat computer sehinga metode pebelajaran aktif dalam jaringan ini dapat dilanjutkan.

Pengabdian ini dilaksanakan dalam dua tahapan, yaitu :

1. Pelatihan menyiapkan rencana pembelajaran dan pembuatan bahan ajar berbasis Teknologi Informatika

2. Pelatihan belajar aktif dalam jaringan atau Daring

Adapun metode yang digunakan pada pelaksanaan pengabdian ini adalah:

1. Memperoleh data berupa informasi dari buku atau kurikulum khusus materi yang akan dibuat aplikasi pembelajarannya 
2. Melakukan identifikasi bagaimana membuat materi yang menarik dan mudah dipahami oleh siswa SMA

3. Untik meningkatkan minat belajar siswa pada materi ini akan di bauat aplikasi pembelajaran yang materinya dikemas seefisien mumgkin, sehingga siswa dapat berinteraksi dengan aplikasi tersebut

4. Melakukan perancangan aplikasi pembelajaran, mulai dari membuat tampilan aplikasi, penyusunan materi, latihan dan soal

5. Setelah perancangan rampung dan diperoleh hasil yang maksimal, maka dilakukan pembagian aplikasi ini ke sekolah dan membuat pelatihan /workshop kepada guru SMA

\section{HASIL DAN PEMBAHASAN (RESULT AND DISCUSSION)}

Pada pengabdian ini ketua tim pengabdian USU memaparkan segala kontribusi dan solusi yang akan diberikan oleh perguruan tinggi khususnya Universitas Sumatera Utara dalam membantu dan membekali sekolah dalam menghadapi tantangan pendidikan menyiapkan generasi revolusi industri 4.0 terutama dalam tahun ini dunia pendidikan harus menghadapi perubahan pembelajaran akibat pandemic Covid-19, sehingga dengan adanya pembekalan dan pelatihan yang diberikan maka akan meningkatkan kualitas sumber daya manusia yang ada di SMA SWASTA SWAKARYA BINJAI. Bantuan ini sangat dibutuhkan oleh SMA Swasta Swakarya Binjai karena selama ini guru melaksanakan pembelajaran jarak jauh hanya menggunakan whatsupp dan didominasi pemberian tugas oleh guru.

Dalam mendiskusikan pelatihan ini yang langsung dipimpin ketua Tim untuk memberikan metode pembelajaran yang dapat diterapkan kepada seluruh siswa di sekolah. Tujuan pelatihan ini dilakukan dengan harapan mampu memberikan edukasi kepada guru-guru supaya pembelajaran lebih aktif dengan tidak melupakan nilai-nila yang harus disertakan pada setiap kegiatan belajar mengajar seperti mengucapkan salam berdoa dan menanamkan nilai nilai Pancasila di dalam kehidupan bermasyarakat. 


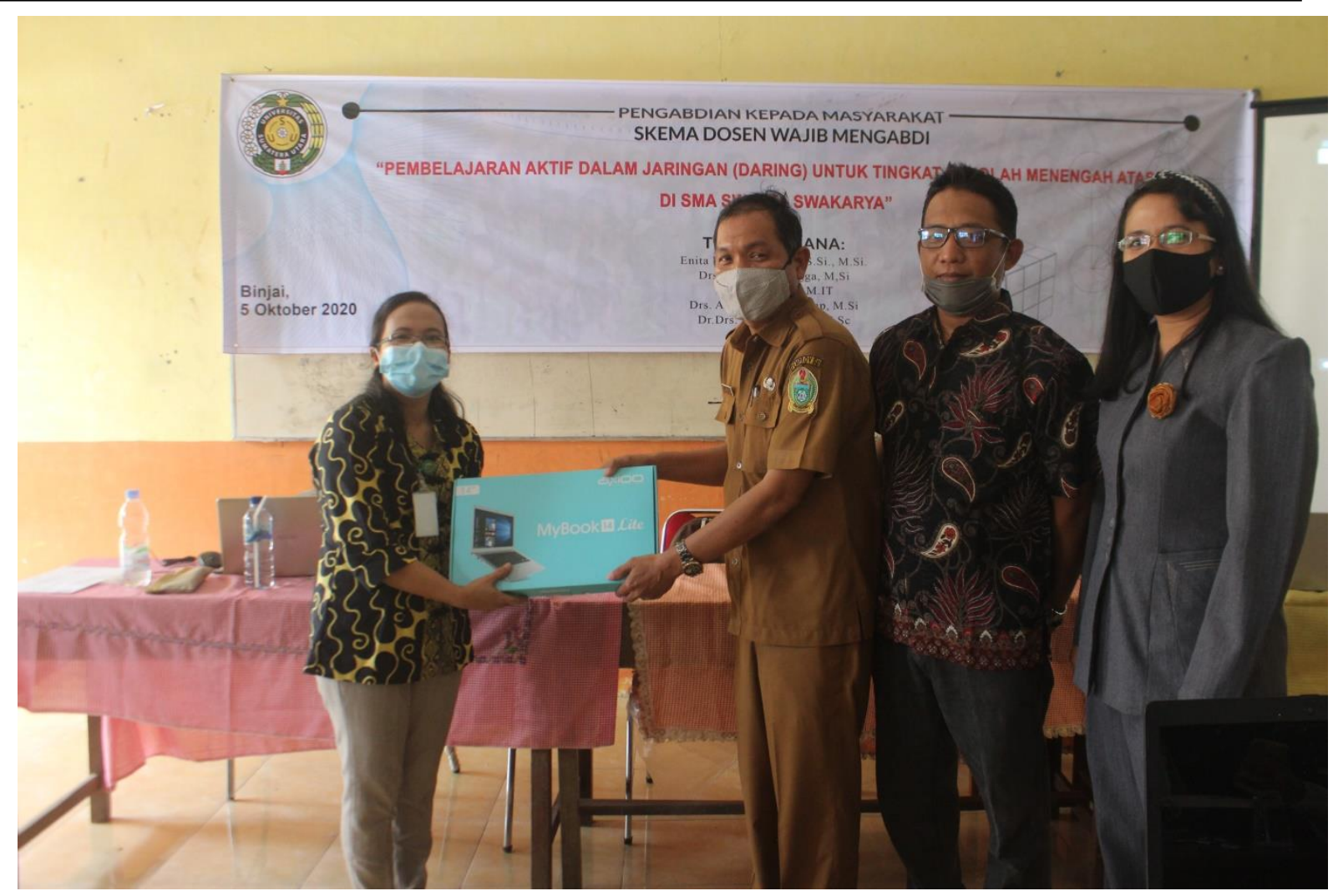

Gambar 3.1. Serah Terima Perangkat Pendukung Pembelajaran Aktif di Sekolah

Pada kegiatan pengabdian ini juga dilakukan serah terima perangkat pendukung dalam menciptakan pembelajaran aktif di sekolah kepada kepala sekolah SMA Swasta SWAKARYA Binjai yaitu berupa 1set Laptop, seminar kit, masker dan modul pelatihan pembelajaran dalam jaringan (Daring). Seluruh perangkat di siapkan Tim guna mendukung peran sekolah di dalam menciptakan generasi yang berkualitas dan adanya suasana pembelajaran yang baru dengan mengedepankan keaktifan peserta didik dan di harapkan peserta didik juga dapat menikmati fasilitas yang mendukung pembelajaran agar menambah motivasi belajar di SMA Swasta SWAKARYA Binjai 


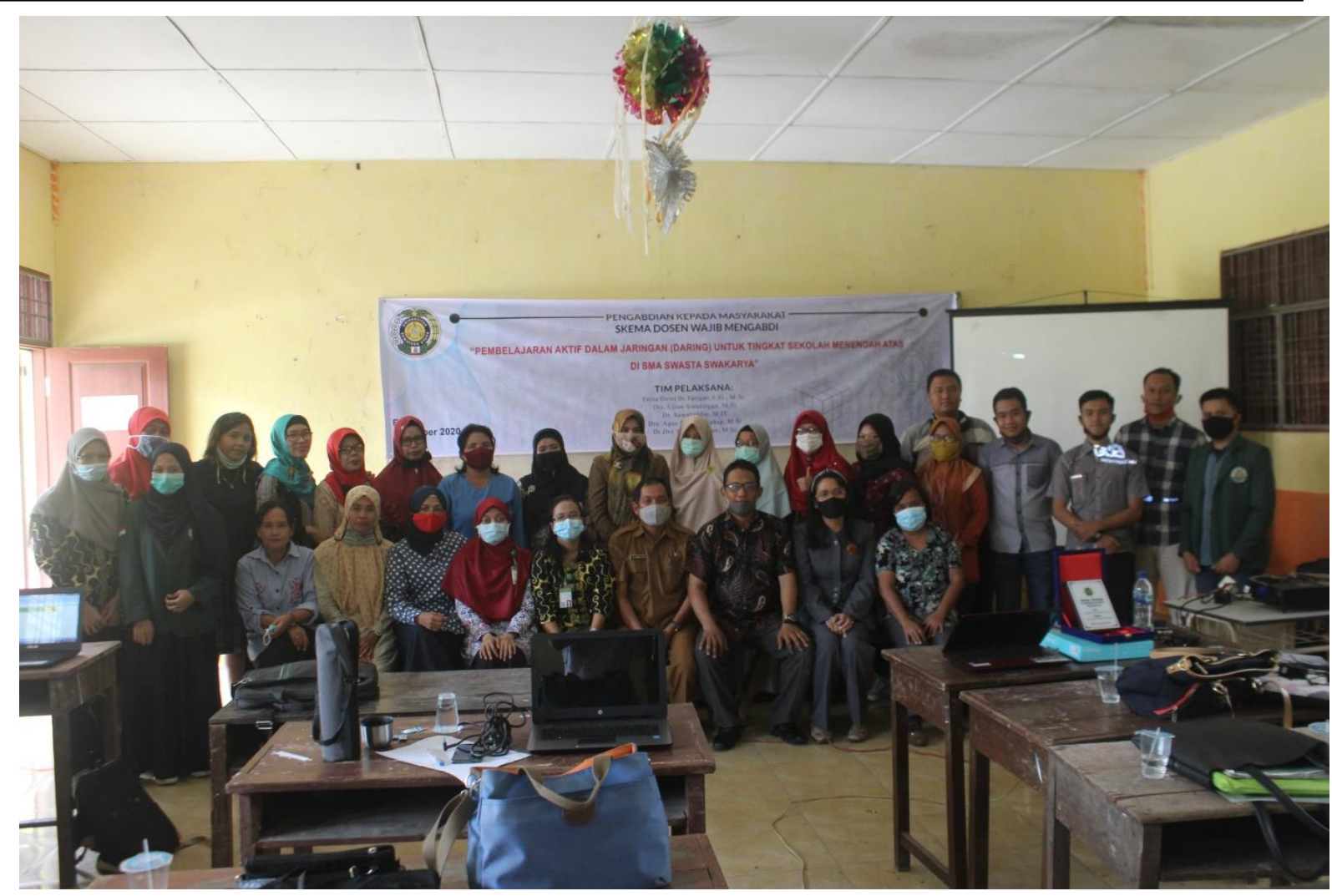

Gambar 3.2. Foto Bersama dengan kepala sekolah dan Guru SMA Swasta SWAKARYA Binjai

\section{KESIMPULAN}

Pada pelaksanaan Pengabdian kepada Masyarakat ini memberikan beberapa hal penting untuk diperhatikan, yaitu:

1. Kegiatan ini (Pengabdian kepada Masyarakat) yang dilakukan sangat penting untuk terus melanjutkannya karena memberi banyak manfaat. Mulai dari diskusi bersama dengan guru guru diperoleh banyak masukan dan saran dalam meningkatkan mutu pendidikan Indonesia.Banyak ditemukan hambatan dalam pelaksanaan saran dan masukan yang dihasilkan dari diskusi bersama ini, yaitu saran dan prasarana yang masih kurang memadai dalam kegitan belajar dan mengajar. Dan minimnya keterlibatan alumni dan pemerintah setempat.

2. Pelatihan materi pembelajaran aktif serta pemberian sarana pembelajaran di sambut dengan ucapan terimakasih dari kepala sekolah dan guru-guru di sekolah, ini menunjukan keingin untuk mengembangkan sekolah sangat tinggi. Dan sewaktu pelatihan banyak guru yang antusias bertanya memperlihatkan keinginan guru untuk dapat menerapkan pembelajaran aktif kepada peserta didik. Dan kegiatan terakhir adalah pemberian materi untuk dapat mengulang pelatihan di rumah dan dapat didiskusikan dengan sesama guru di sekolah SMA Swasta Swakarya Binjai

\section{UCAPAN TERIMAKASIH (ACKNOWLEDGMENTS)}

Artikel ini merupakan salah satu hasil dari Program Pengabdian kepada Masyarakat yang Dibiayai oleh dana NON PNBP Universitas Sumatera Utara dengan skema Dosen Wajib Mengabdi. Oleh karena itu, diucapkan terima kasih kepada Rektor Universitas Sumatera Utara atas dukungan dana dan fasilitas yang diberikan. Terima kasih juga kepada Mitra pada kegiatan pengabdian ini. 
E.D. Tarigan, et al Active learning in online teaching in SMA Swakarya Binjai

http://abdimas.usu.ac.id

\section{DAFTAR PUSTAKA}

HomeEdition. 2005, Macromedia flash Profesional 8 help, Macromedia Inc

Juhaeri. 2009. Pengantar Multimedia untuk Media Pembelajaran bagian I, Ilmu Komputer.

Retno, Margono dan Bambang Eka Purnama. ISSN 1979 - 9330. Study of Interaktif Recognition Letter and Number For Children With Computer Multimedia. Indonesian jurnal on Computer Science - Speed (IJCSS) 4 Vol. 3 Nomor 1 Agustus 2008

T.J. Marpaung, Dewi Sartika br Ginting,Andy Candra dan J.L. Marpaung. 2020. Active learning for middle school based on information technology in SMA Negeri 1 Dolok Batu Nanggar. Abdimas Talenta. Vol. 5 No. 2 pp. 127-132 